\title{
当教室16年間の気管・気管支異物の臨床統計的観察
}

\author{
山本 真一郎*, 板 谷 知 己** \\ 馬 場 駿 吉*
}

\section{A Statistical Review of Clinical Cases with Tracheo-bronchial Foreign Bodies Treated in Our Clinic during the Last 16 Years}

\author{
Shin-ichiro Yamamoto, M.D.," Tomomi Itaya, M.D.,** and Shunkichi Baba, M.D.* \\ *Department of Otorhinolaryngology, Nagoya City University, Nagoya, and \\ ** Department of Otorhinolaryngology, Koseiren Kainan Hospital, Nagoya
}

\begin{abstract}
A statistical study was made on foreign bodies in the trachea and bronchi in 59 patients (male : female $=40: 19$ ) hospitalized in our clinic between 1976 and 1991. Forty-nine patients were under 2 years of age. Peanuts predominated (37 cases, $62.7 \%$ ) in the kinds of foreign bodies. The foreign bodies were found in the right bronchus in 24 patients, in the left bronchus in 21 patients and in trachea in 8 patients.
\end{abstract}

Key words : tracheo-bronchial foreign bodies, statistical review, Nagoya City University

\section{I .はじめに}

気管・気管支異物は耳鼻咽喉科領域における 救急疾患の中では最も緊急度の高いものであ り, 直接生命に危険を及ぼす場合も少なくない。 今回われわれは当教室16年間における気管・気 管支異物について統計観察を行ったので報告す る。

\section{II. 対 象}

対象は1976年 1月より1991年12月までの16年 間に名古屋市立大学病院耳鼻咽喉科に気管・気 管支異物, あるいはその疑いにて入院加療し, 実際に異物が確認された59例である。これらの 症例に対し, 異物の年度別発症頻度, 男女差,

*名古屋市立大学医学部耳鼻咽喉科学教室, **愛知県 厚生連海南病院耳鼻咽喉科

別刷請求： 7467 愛知県名古屋市瑞穂区瑞穂町字川 澄 1 名古屋市立大学医学部耳鼻咽喉科 学教室 山本真一郎

投稿受付：1992年 1月28日
種類, 年齢, 受診月, 介在部位, 合併症等につ いて臨床統計的観察を行った。

\section{III. 結 果}

1. 年次別および性別症例数（図 1)

過去16年間の気管・気管支異物総数は59例で 年間平均 3.7 例であり, 年々減少傾向にあった。 性別では男性40例，女性19例であり，男性が女 性の約 2 倍多かった。

\section{2. 年齢と性別（図 2)}

年齢別では 1 歳が31例 (52.7\%) と最も多く, 2 歳以下で合計 49 例と, 全体の $83.1 \%$ 占めて

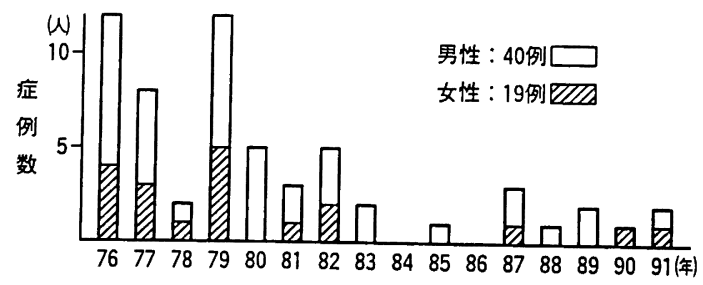

図 1 気管・気管支異物の年次別および性別分布 
日気食会報，43（5），1992

いた。

\section{3.月別発生頻度（図 3)}

月別では 1 月， 5 月， 2 月に多く, 冬と春に 多い傾向にあった。

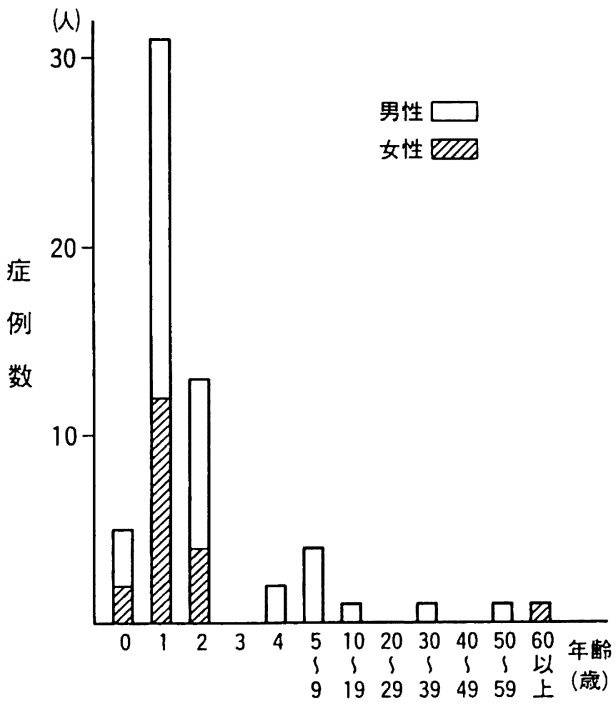

図 2 気管・気管支異物の年齢別および性別分布

\section{4. 異物の種類と年齢（表 1)}

異物の種類をX線透過性異物とX線非透過性 異物に分類すると前者は50例 (84.7\%)，後者は 9 例（15.3\%）とX線透過性異物が多かった。

$\mathrm{X}$ 線透過性異物ではピーナツが37例と最も多 く, 次いでピーナツ以外の豆類 8 例, 玩具のプ ラスチック製ピストルの弾 2 例と続いていた。 ピーナツ等の豆類は合計 45 例と全症例の $76.3 \%$ を占めており，また 43 例が 4 歳以下に集中して いた。

X線非透過性異物ではまち針，義歯，歯冠等 がみられたが，合計 9 例とX線透過性異物に比 して少なかった。

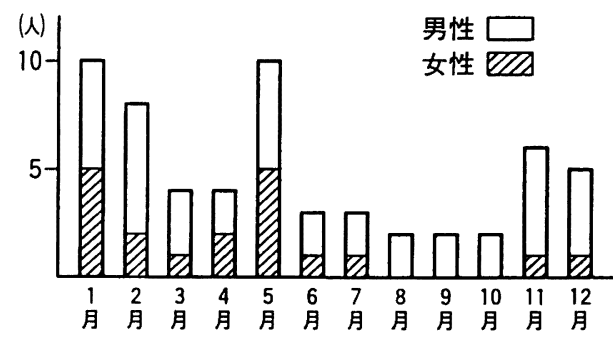

図 3 気管・気管支異物の月別発生頻度

表 1 気管・気管支異物の種類と年齢

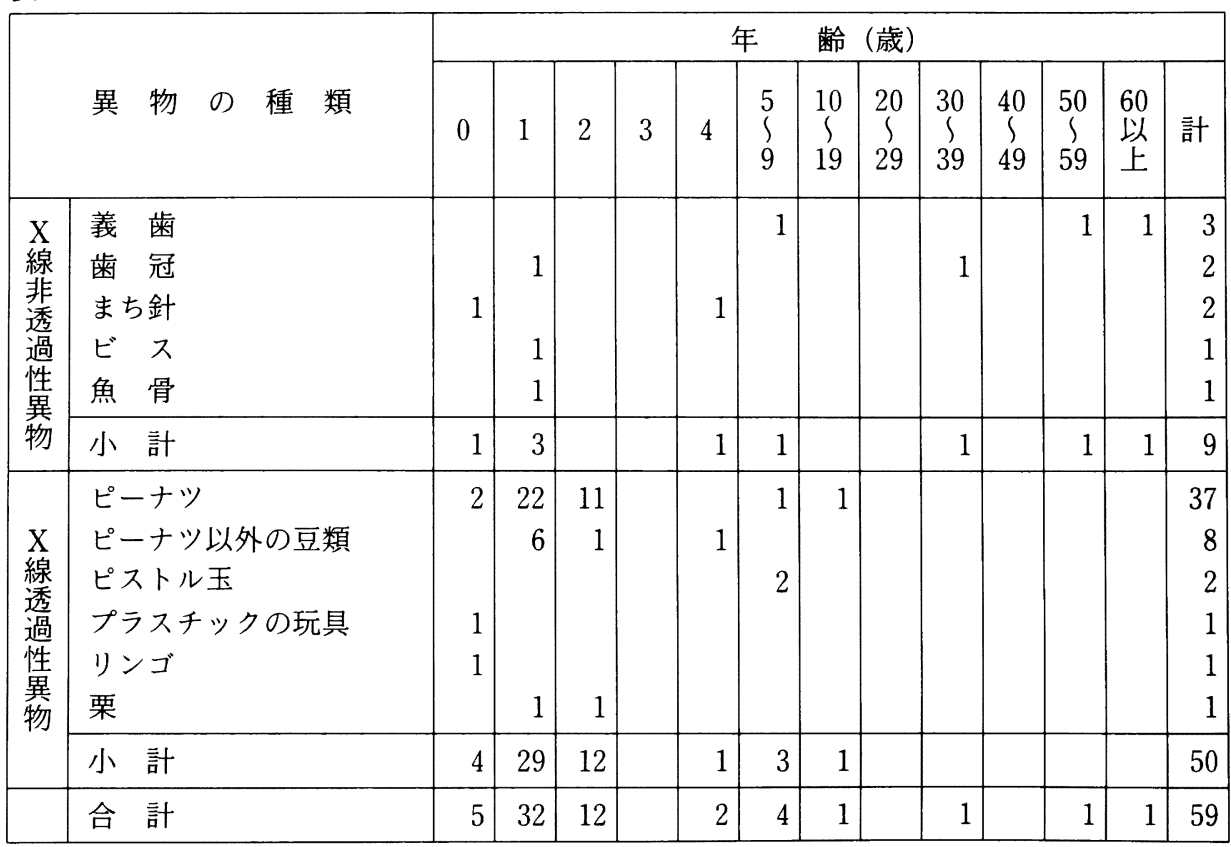


表 2 気管・気管支異物の種類と介在部位

\begin{tabular}{|c|c|c|c|c|c|c|c|}
\hline & & & & 介 在 部 & 位 & & \\
\hline & 異 物 の 種 類 & $\begin{array}{l}\text { 気管 } \\
(\mathrm{T})\end{array}$ & $\begin{array}{c}\text { 右気管支 } \\
(\mathrm{R})\end{array}$ & $\begin{array}{c}\text { 左気管支 } \\
\text { (L) }\end{array}$ & $\mathrm{R}+\mathrm{L}$ & $T+R$ & 計 \\
\hline $\mathrm{X}$ & 義 歯 & 1 & & 2 & & & 3 \\
\hline $\begin{array}{l}\text { 線 } \\
\text { 䪞 }\end{array}$ & 歯 冠 & & 1 & 1 & & & 2 \\
\hline 棐 & まち針 & 2 & & & & & 2 \\
\hline 薖 & ビ ス & 1 & & & & & 1 \\
\hline 性 & 魚 骨 & 1 & & & & & 1 \\
\hline 物 & 小 計 & 5 & 1 & 3 & & & 9 \\
\hline & ピーナツ & 3 & 16 & 13 & 4 & 1 & 37 \\
\hline $\mathrm{X}$ & ピーナツ以外の豆類 & & 5 & 2 & 1 & & 8 \\
\hline 線 & ピストル玉 & & & 2 & & & 2 \\
\hline 過 & プラスチックの玩具 & & 1 & & & & 1 \\
\hline 性 & リンゴ & & 1 & & & & 1 \\
\hline 巷 & & & & 1 & & & 1 \\
\hline & 小 計 & 3 & 23 & 18 & 5 & 1 & 50 \\
\hline & 合 計 & 8 & 24 & 21 & 5 & 1 & 59 \\
\hline
\end{tabular}

表 3 気管・気管支異物の介在部位と年齢

\begin{tabular}{|c|c|c|c|c|c|c|c|c|}
\hline \multirow[b]{2}{*}{ 介在部位 } & \multicolumn{4}{|c|}{ 年 } & \multicolumn{4}{|c|}{ 齢 (歳) } \\
\hline & 0 & 1 & 2 & 3 & 4 & $\int_{9}^{5}$ & $\begin{array}{l}10 \\
\text { 以 } \\
\text { 上 }\end{array}$ & 計 \\
\hline 気管(T) & 1 & 5 & & & 1 & & 1 & 8 \\
\hline 右気管支 $(\mathrm{R})$ & 2 & 13 & 6 & & 1 & 1 & 1 & 24 \\
\hline 左気管支 (L) & 1 & 10 & 5 & & & 3 & 2 & 21 \\
\hline $\mathrm{R}+\mathrm{L}$ & 1 & 3 & 1 & & & & & 5 \\
\hline $\mathrm{T}+\mathrm{R}+\mathrm{L}$ & & & 1 & & & & & 1 \\
\hline 計 & 13 & 31 & 13 & & 2 & 4 & 4 & 59 \\
\hline
\end{tabular}

\section{5. 異物の種類と介在部位（表 2）}

異物の介在部位は右気管支24例, 左気管支 21 例, 気管 8 例の順であり, 右気管支にやや多か った。異物の種類と介在部位との間には特に関 係は認めなかった。

\section{6. 異物の介在部位と年齢（表 3 ）}

4 歳以下では右気管支にやや多かったが，年 齢別による左右差は特に認めなかった。

\section{7 . 転帰, 術後合併症等}

59例中, 死亡症例が 1 例, 1 回の摘出術では 摘出し得ず後日再摘出術を要した症例が 3 例,
術後縦隔気腫を生じた症例が 2 例あった他は特 に重篤な合併症はなかった。

\section{IV. 考 察}

気管・気管支異物はわれわれ耳鼻咽喉科・頭 頸部外科領域における救急医療の中では最も重 要な位置を占めている。また，この領域は麻酔 方法や摘出機器等の進歩による摘出方法の変遷 がめざましく，医療をとりまく生活環境や社会 情勢等の影響を受けやすい分野でもある。本論 文は1976年 1 月より1991年12月までの16年間に おける当教室の統計的観察であるが, 摘出に当 たっては全例全身麻酔下に ventilation bronchoscope を使用しており, また, 気管切開施行 例は一例もなかった。従来は局所麻酔下の摘出 や気管切開下の摘出も多く行われていたが, 最 近の報告 ${ }^{110)}$ ではこうした摘出方法は次第に減 少しつつある。当教室も同様の傾向であり, 本 稿では1976年以降という比較的最近の症例につ いて集計したためか, 局所麻酔下や気管切開下 で摘出した症例は認めなかった。

異物の男女比は諸家の報告 ${ }^{1 \sim 9,111}$ と同様に当 教室においても男性が女性の約 2 倍と多かっ た。 
年次別発生頻度では文献的 ${ }^{1,7 \sim 12)}$ には特に一一 定の傾向は認めないが, 当教室においては年々 減少傾向にあった。16年間の年間平均症例数は 3.7 例であるが, 1982 年以降の 10 年間では年間平 均1.7例であり, 大学病院としては他施設 $1,5,6,8,12)$ と比較した場合非常に少ないように思われる。 これは, 最近救急医療に参加する施設における 摘出例の増加もあり, また, 当院が都市部にあ り, 気管・気管支異物に対する啓蒙によるとこ ろが大きいのではないかと考える。また, 気管・ 気管支異物の発生年齢層の大多数を占める乳幼 児人口の減少傾向も影響しているかもしれな い。

月別発生頻度では，5月を除けば11月より翌 年 2 月までの冬季に多い傾向が見られた。この 季節は気管・気管支異物の大多数を占めるピー ナツの出回る時期であり,この事実との関連を 述べている報告3)もあるが, 現在ピーナツの入 手に季節性があるとは考えられない。しかし患 者の年齢層の主体は乳幼児であって, 冬季には ピーナツを与える保護者とともに室内に閉じこ もりがちになることも, この時期に発生頻度が 高まる一因ではないだろうか。

異物の種類ではX線透過性異物が多く，中で もピーナツが 37 例と最も多く全症例の $62.7 \%$ と 過半数を占めており, ピーナツ以外の豆類 8 例 (13.6\%) を含めると豆類で 45 例 $(76.3 \%)$ と全 症例の約 4 分の 3 を占めていた。ピーナツ等の 豆類が最も多いのは諸家の報告 ${ }^{1212)}$ と同様であ った。また年齢では 2 歳以下に 49 例（83.1\%） と大多数が集中しており，2 歳以下 49 例中 42 例 が豆類であった。諸家の報告1,10,12)にあるよう に, 乳幼児, 特に 2 歳以下の乳幼児にはピーナ ツを与えてはいけないという啓蒙は事故予防と して非常に重要であり, 保護者の細心の注意が 必要であることをここでも強調しておきたい。 なおピーナツ異物の最高年齢は10歳であった。

気管支異物の介在部位に関しては, 右側に多 いとする報告2,4,7 11) が従来多い。その理由とし て右気管支の方が太く, 気管軸に対して曲がり 方が少なく, 呼気量も大きいこと,さらに気管 カリナの位置が左に偏っていること, 気管筋の 働きが関係していることなど13 16) があげられ る。しかしながら左側に多いとする報告5,6,17,18)
や左右差を認めないとする報告 ${ }^{1,3)}$ も見られる。 当教室の結果では右気管支24例, 左気管支21例 と若干右側に多かったものの特に左右差は認め なかった。

Daniilidis ら ${ }^{19)}$ は，子供が寝転んでいるとき に右手に異物を持っている状況では左気管支が 気管軸に対して曲がり方が少なくなるため異物 は左側に多いと報告している。また, Link ${ }^{20)}$ は 乳幼児では気管が右側に彎曲しているため左気 管支が気管軸に対して曲がり方が少なくなり異 物は左側に多いと報告している。

いずれにせよ気管支異物は左右どちらにも生 じ得るということを念頭に置かねばならない。 さらに今回の検討では複数部位に異物が介在し ていた症例も6 例 (10.2\%) 認められた。気管・ 気管支異物は術前に介在部位を確定することが 困難なことも多い。摘出時に気管から両側の気 管支にかけての注意深い観察が常に必要である ことも忘れてはならない。

\section{$\mathrm{V}$.まとめ}

1976年 1 月より 1991年12月までの16年間に当 教室にて入院加療した気管気管支異物59例につ いて，統計的観察を行い報告した。

1) 男性40例, 女性19例で男性が約 2 倍多く, 発生頻度は年々減少傾向にあった。

2 ) 年齢では, 2 歳以下の乳幼児が49例(83.1 \%) と大多数を占めていた。

3 ）種類では，ピーナツが37例 $(62.7 \%)$ と 最も多く，他の豆類を含めると豆類全体で 45 例 (76.7\%) であった。

4 ）介在部位では, 右気管支24例, 左気管支 21 例, 気管 8 例, その他 6 例の順であった。

5 ）気管支異物は左右どちらの気管支にも起 こり得ること, 複数の部位に介在することもあ ることを摘出の際に念頭におかねばならない。

\section{文献}

1) 牧 清人, 安岡義人, 原田 紀・他：当教室 25 年間の気管・気管支異物の統計的観察.耳鼻臨 床, 77 ：增 2；666-671，1984。

2 ) 粟田口省吾, 宮野和夫, 円山宏洋 - 他 : 気管 気管支異物63例の臨床的検討. 日気食会報, 31 ： 315-321, 1980.

3 ）大戸武久, 内田 豊, 遠藤朝彦・他：当教室 10 年間の気道および食道異物の臨床統計的観察。 
日気食会報，32：241-248，1981.

$4 ）$ 小玉直志，小川克二，菊田 晃・他：最近 10 年 間の当教室に於ける下気道ピーナツ異物症例の 統計的観察. 耳鼻臨床, 71:275-281, 1978.

5 ）西条 茂, 富岡幸子, 高坂知節・他：Ventilation Bronchoscopeにより摘出した気道異物 100 症 例の統計的観察。日気食会報，28:211-216， 1977.

6）西条 茂, 郭 安雄, 佐藤雅弘・他：気道異物 症例の統計的観察. 耳鼻, 319-322, 1979.

7 ）仁瓶誠五, 樋渡章二, 大八木章博・他：当院に おける気管気管支異物 10 年の統計的観察と興味 ある若干例について.耳鼻臨床, 76：增 1：753$763,1983$.

8 ）桶口彰宏, 鈴木 徹, 斎藤 彰・他：開院以来 10 年間の気道食道異物の統計的観察. 日気食会 報, $34: 255-259,1983$.

9 ）桑内隆郎, 西村忠郎, 高須昭彦・他：当教室開 設時より 7 年間の食道および気管・気管支異物 の統計的観察。日気食会報, 32:339-344, 1981.

10）堤康一朗, 戸田行雄, 飯田 順・他：当教室 10 年間の気道及び食道異物の臨床統計的観察.耳 鼻臨床, 補 9:59-65, 1987.

11）小村 良, 佐藤英治, 酒井利忠・他：食道およ び気管・気管支異物の統計的観察。耳鼻臨床, 補27：170-182, 1988.
12）松永 喬, 太田和博: 気道・食道異物症の予防. JOHNS, $4: 1093-1100,1988$.

13）鈴木篤郎：耳鼻咽喉科学入門, pp.273-275, 南山 堂, 東京, 1980 .

14）金子省三，日野原正，秋山欣治・他：小児気管 支異物の介在側について. 日気食会報, $33: 31$ 36, 1982.

15) 東紘一郎，戸川 清 : 気管分岐部の形態一気管 支異物存在部位と関連して一. 日気食会報, 33 : 245-249, 1982.

16) Jackson, C., and Jackson, C.L. : Bronchoesophagology, pp.68-109, W.B.Sanders Company, Philadelphia, 1950.

17）丘村 熙，兵頭政光，稲木匠子：気管・気管支 異物の診断と摘出法。耳喉, $63: 847-852,1991$.

18) Cohen, S.R., Herbert, W.I., Lewis, G.B., Jr., et al. : Foreign bodies in the airway. Five year retrospective study with special reference to management. Ann. Otol., 89 : 437-442, 1980.

19) Daniilidis, J., Symeonidis, B., Triaridis, K., et al. : Foreign body in the airways. A review of 90 cases. Arch. Otolaryngol., $103: 570-573$, 1977.

20) Link, R. : Fremdkörper der Trachea und der Bronchien. Hals-Nasen-Ohren-Heilkund in Praxis und Klinik Band 2, 33:1-17, 1977. 